\title{
LEGAL MEANS OF ENSURING COMPETITION IN PHARMACY
}

DOI: 10.36740/WLek202012201

\author{
Nataliya Gutorova', Vitalii Pashkov' ${ }^{1}$, Oleksii Soloviov $^{2}$ \\ 'POLTAVA LAW INSTITUTE OF YAROSLAV MUDRIY NATIONAL LAW UNIVERSITY, POLTAVA, UKRAINE \\ ${ }^{2}$ NATIONAL SECURITY AND DEFENSE COUNCIL OF UKRAINE, KYIV, UKRAINE
}

\begin{abstract}
The aim: To research the consequences of pharmacy chains monopolization and establishment of legal means of neutralization of such consequences.

Materials and methods: The study is based on acts of the European Union, the United States, and Ukraine and international regulations and documents on health care. The study's materials were the results of a questionnaire survey of managers and specialists in a pharmacy on marketing contracts. The views of scientists on the above issue were also studied. The study analyzes generalized information from scientific journals using scientific, legal methods. Among the main research methods are systematic approach, analytical, statistical, comparative, dialectical, graphical, and a questionnaire survey of respondents.

Results: Consolidation of massive pharmacy chains leads to an artificial increase in drug prices by almost 50 percent, which significantly reduces their availability to patients, and in many cases, makes treatment impossible due to lack of funds.

Conclusions: As a result of further monopolization of the pharmacy market, the pharmaceutical industry, small pharmacy enterprises, and the complete distribution of medicines will be destroyed.
\end{abstract}

KEY WORDS: pharmacy chains, monopolization of pharmacies, marketing services in pharmacy

Wiad Lek. 2020;73(12 p. II):2701-2708

\section{INTRODUCTION}

The process of horizontal integration in the retail segment, which is manifested in the formation of large pharmacy chains, is typical for pharmaceutical companies, especially in recent years.

The pharmacy network can be both individual pharmacies (centralized networks) and their totality (holding type networks), united by a joint owner or on several contractual parameters (goals, means, brand, etc.). However, holding pharmacy networks may include dozens of licensees. This type of integration has both several advantages (the possibility of promotional projects, a system of discounts and bonuses, etc.) and disadvantages. One of the most significant disadvantages of the existence of pharmacy chains, particularly if they occupy a large market share, is the monopoly on the retail sale of medicines and, consequently, the process of uncontrolled pricing of medicines [1]. Besides, the researchers emphasize, pharmacy chains cannot provide adequate quality of services [2].

This state of affairs among European countries is most common in Ukraine and, until recently, these problems existed in Poland and Hungary. However, these countries have timely amended their legislation to improve pharmaceutical care quality and combat monopolies among pharmacies. Given that the pharmacist is in direct contact with the patient, these countries have embarked on the path of establishing pharmaceutical activity as a professional and have established special requirements for the founders of pharmacies. However, most EU countries, in particular Germany, have never abandoned the principle of professionalism, i.e., the principle of "one pharmacist one pharmacy".

\section{THE AIM}

To research the consequences of pharmacy chains monopolization and establishment of legal means of neutralization of such consequences.

\section{MATERIALS AND METHODS}

The study is based on acts of the European Union, the United States, and Ukraine and international regulations and documents on health care. The study's materials were the results of a questionnaire survey of managers and specialists in a pharmacy on marketing contracts. The views of scientists on the above issue were also studied. The study analyzes generalized information from scientific journals using scientific methods from a medical and legal perspective. Among the main research methods are systematic approach, analytical, statistical, comparative, dialectical, graphical, and a questionnaire survey of respondents.

\section{RESULTS AND DISCUSSION}

It should be noted that many European countries have an active policy of combating pharmacy chains, provide the opportunity to open a pharmacy only to professionals 
Table 1. Results of the analysis of the requirements for the implementation of pharmacy activities in different European countries

\begin{tabular}{|c|c|c|c|c|c|}
\hline $\begin{array}{l}\text { Name of } \\
\text { country }\end{array}$ & $\begin{array}{l}\text { Qualification } \\
\text { requirements } \\
\text { for founders }\end{array}$ & $\begin{array}{c}\text { Requirements for } \\
\text { the qualification of } \\
\text { the management of } \\
\text { pharmacies }\end{array}$ & $\begin{array}{l}\text { Requirements for } \\
\text { the geographical } \\
\text { location of } \\
\text { pharmacies }\end{array}$ & $\begin{array}{l}\text { Demographic } \\
\text { requirements }\end{array}$ & $\begin{array}{l}\text { Limiting the number } \\
\text { of pharmacies per } \\
\text { pharmacy operator }\end{array}$ \\
\hline Austria & yes & yes & $500 \mathrm{~m}$. & 5500 persons & 4 pharmacies \\
\hline Hungary & Yes & Yes & $250 \mathrm{~m}$. & $4000-4500$ persons & 4 pharmacies \\
\hline Italy & Yes & Yes & $200 \mathrm{~m}$. & $3000-5000$ persons & absent \\
\hline France & Yes & Yes & No & $2500-3000$ persons & 4 pharmacies \\
\hline Spain & Yes & Yes & $250 \mathrm{~m}$. & 2800 persons & 4 pharmacies \\
\hline Estonia & No & Yes & $500 \mathrm{~m}$. & 3000 persons & 4 pharmacies \\
\hline Germany & Yes & Yes & No & No & 4 pharmacies \\
\hline Finland & Yes & Yes & certain territory & No & 4 pharmacies \\
\hline Cyprus & Yes & Yes & certain territory & No & 1 pharmacy \\
\hline Denmark & Yes & Yes & certain territory & No & 1 pharmacy \\
\hline Latvia & Yes & Yes & $500 \mathrm{~m}$. & 3000 persons & No \\
\hline
\end{tabular}

with specialized education, and impose restrictions on the number of pharmacy enterprises by various criteria. Also, scientists believe that chain pharmacies are expanding in many low and middle-income countries [3].

The fact is that unlike other activities: we do not choose drugs, but we are prescribed them. Furthermore, the pharmacy is, first of all, a health care institution, not a trading enterprise, and the primary purpose of the pharmacy, like any health care institution, is to perform the functions of medical care as one of the chains of ensuring the right to health. Therefore, most EU countries set professionalism requirements for pharmacy activities, not only for pharmacy workers but also for pharmacy founders, limiting their number depending on population and pedestrian accessibility.

Thus, the report of the WHO European Bureau on the legal and regulatory status of pharmacy (The legal and regulatory framework for community pharmacies in the WHO European Region) [4] refers to the existing restrictions on the specifics of doing business in the pharmacy segment.

The first thing to pay attention to is the qualification restrictions on the right to own pharmacies. For example, in Germany, Estonia, Finland, France, Luxembourg, Austria, Poland, Slovenia, Spain, Hungary, in Cyprus, pharmacies are owned only by specialists (pharmacists). Moreover, the European Court in 2009 (on the example of Germany and Italy) concluded that the guarantee of freedom of enterprise and free movement of capital are not obstacles to the prohibition at the national legislation level of pharmacy ownership for non-pharmacists (Case C-531/06) [5]. A Member State has the right to consider a pharmacy headed by a non-pharmacist as posing a risk to public health.
The WHO European Office then draws attention to the existing restrictions on the number of pharmacies.

Thus, in Bulgaria, Estonia, France, Hungary, Poland, Portugal, there are restrictions - no more than four pharmacies per owner. Multiple ownership is prohibited in Denmark, Finland, Germany, Spain, Turkey, Monaco. In virtually all EU countries, there are population restrictions per pharmacy. Also, there are other restrictions, including the availability of pedestrian accessibility, a ban on communication with medical representatives, and so on.

The results of the analysis of the requirements for the implementation of pharmacy activities in different European countries are analyzed and presented in table 1.

It should also be noted that in most European countries, there are restrictions on demographic and / or geographical criteria. Attention is also paid to the management of pharmacies; in most cases, it is pharmacists who are also the founders of these pharmacies [6]. In such conditions, it is necessary to mention the experience of some European countries and, even not those where the principle "one pharmacist - one pharmacy" continues to operate today. These are the countries that first followed the deregulation path and then came to their senses, particularly Poland and Hungary.

In fact, all pharmaceutical specialists know about the experience of Poland. The key elimination of deregulation's consequences began in Poland with the adoption of the Law of the Republic of Poland "On Amendments to the Law" On Pharmaceutical Law "of 06.09.2001" of 07.04.2017. It amended the Law of the Republic of Poland "On Pharmaceutical Law" of 06.09.2001 [7].

The main message is the following requirements: 1) a pharmacy license can be issued if the number of residents 
per public pharmacy in the area is at least 3000 people as of the date of application (for a license), and the distance between the planned location pharmacy and the nearest pharmacy is at least 500 meters in a straight line; 2) pharmacy management can be carried out only professionally based on a pharmacy license.

However, not many people remember that in Poland, until 2008, only a pharmacist by education could manage one pharmacy. However, in 2008-2017 there was a redistribution in favor of massive pharmacy chains. And it was then that the citizens of Poland felt the deterioration of the quality of pharmaceutical services.

That is, Poland and Ukraine's pharmacy market, where for some period of time was formed according to a single scenario.

At the same time, the example of Hungary was the impetus for Poland to make changes. From 2007 to 2010, Hungary followed a course of market deregulation. According to analysts, such a policy has helped create a healthy competitive environment and lower pharmaceuticals prices. However, the Hungarian government drew other conclusions: it was decided at a high level that deregulation had led to a reduction in the quality of service in pharmacies, as well as to their availability in rural areas and, as a result, in Hungary, the rules of operation in the Hungarian pharmacy market changed in 2011.

Thus, according to the new version of the law "Gyftv" [8] in Hungary to own a pharmacy was allowed only to a pharmacist (during the period of market deregulation, anyone could open a pharmacy). And those owners who managed to open a pharmacy business during the legislative "thaw", but do not have the appropriate diploma, are ordered to sell or close it by early 2017 . The distance between pharmacies must now be at least $300 \mathrm{~m}$; one pharmacy serves 4.5 thousand inhabitants. In large cities, the requirements are a little softer: the distance between pharmacies - at least $250 \mathrm{~m}$, and one pharmacy has 4 thousand inhabitants.

Compared to other sectors of the economy, it is no secret that the pharmaceutical industry is the least vulnerable to the crises that have occurred in recent years.

However, in Ukraine, there are different views on the prospects for further development of the retail pharmacy market. Moreover, the most exciting thing is that the pharmaceutical market subjects and the subjects of retail pharmacy networks have contradictory plans for further coexistence.

Thus, the hidden monopolization of pharmacy chains, the creation of unfavorable conditions for small pharmacies that do not withstand unfair competition, the further destruction of municipal and state pharmacy networks, with their gradual depletion in rural areas, lead to the final consolidation in the retail pharmacy market of several final beneficiaries which actually own retail pharmacy chains in the Ukrainian market. Furthermore, it is they who are currently deciding the fate of pharmaceutical manufacturers and distributors. As a result, the price of medicines in Ukraine is inflated by almost 50 percent due to the cost of so-called marketing services, according to the Antimonop- oly Committee of Ukraine in a letter №126-29 / 01-14481 dated November 8, 2019, addressed to the "Patients of Ukraine" Charitable Foundation. Besides, the official of the Antimonopoly Committee of Ukraine drew attention to the well-known concept of the so-called power of the buyer (the drug manufacturer), i.e., a situation where there seem to be no signs of monopoly (dominant) position, but in negotiations, such a buyer is stronger than the seller. She added: "Unfortunately, no one has yet developed a truly effective way to combat such manifestations through the tools of competition law" [9].

That raises a few questions: what are the services causing such a significant increase in the cost of medicines? Who sets the price of medicines, and do marketing services really affect the structure of the pharmacy market? With whom contracts for marketing services are concluded, and who initiates their conclusion?

The task of marketing contracts is to provide services to promote drugs, primarily the manufacturer who has entered into a "marketing agreement" with the pharmacy. Furthermore, here the question arises: how should a pharmacy, which, according to current legislation, is a health care institution, increase sales of certain drugs? Doesn't this mean that the pharmacist by communicating directly with the patient during the release of medicines, undertakes to promote specific products? The situation regarding the prescription drugs is more than strange: any promotion of them by advertising, placement in the service hall in shop windows, in glass and open cabinets, as well as selling without a prescription in Ukraine is officially prohibited.

Researchers of Poltava Law Institute, together with representatives of the pharmaceutical and medical community in 2019 - 2020, conducted a survey of pharmaceutical workers in the Poltava region in order to determine criteria for purchasing pharmaceutical products from manufacturers. As a result, there are trends in the purchase of pharmaceutical products depending on the amount of interest on the purchased pharmaceutical products, which is related to the volume of purchased goods. Purposeful selection of respondent experts was carried out, taking into account the following main factors: high level of education and qualification, availability of the necessary professional experience, and the ability to influence the purchase of pharmaceutical products. In accordance with the purpose of the study, respondents were interviewed on the fact of concluding marketing agreements, involving intermediaries in concluding marketing agreements, and establishing criteria for suppliers of pharmaceutical products depending on the terms of marketing agreements.

The majority of respondents indicated that they actively offer marketing contracts for concluding, for example, the following companies with foreign capital: Mega Livesciences, MOVI HELLS, Organistin LTD, Abbott Ukraine, GLEDPHARM LTD, Asino Ukraine, Alpen Pharma AG, Astrapharm, Unipharm Ukraine, Medo Bayer, Unipharm Ukraine, Dolphi Ukraine, Konark Intermed, Nobel Ilach Sanai Ve Ticaret Anonymous Shirketi, Polpharma, Stada Ukraine, Reckitt Benkiser Ukraine, etc. Interestingly, Asino Ukraine includes 
such prescription drugs as Diocor Solo in tablets, Lamotrin, Levocord Retard Asino among GLADPHARM LTD, and such prescription drugs are included in GLEDPHARM LTD. as "Fanigan" in tablets. That is, there is a promotion of goods that a priori are not subject to the promotion.

Among domestic manufacturers and importers of pharmaceutical products, such companies as Phyto Lek LLC, PJSC Khimpharmzavod Chervona Zirka PJSC, Kyiv Vitamin Plant PJSC, Astrapharm LLC, Novalik Pharm LLC, LLC "Production and trading company Sarepta", LLC "Micropharm", LLC "Ternopharm", LLC "Medico", LLC "Pharma House“, LLC "Medical Center MTK“, PJSC Research and Production Center Borshchahiv Chemical-Pharmaceutical Plant, 1A Diagnostic Company LLC, PJSC Lubnipharm, Agropharm LLC, etc. are actively offering marketing contracts to pharmacy chains for concluding marketing agreements.

PJSC "Kyiv Vitamin Plant" offers an impressive form of payment for marketing agreements: 75 multiplied by the number of units of goods and the number of pharmacies (in the presence of 100 pharmacies 750000 UAH paid to the owner of the pharmacy network for 100 items, which is approximately 45 thousand euros). And for example, PJSC "Lubnipharm" offers from 15 to 25 percent surcharge for the goods received under marketing contracts to pharmacy chains.

A separate part of importers, domestic manufacturers, marketing organizations enters into marketing agreements with pharmacy chains through intermediaries under the "gray schemes." For example, Olive Pharm Service LLC, B2B Pharm LLC, B2B Pharm Service LLC, B2B Pharm Company LLC, B2B Pharm Group LLC. All of these companies have the same final beneficiaries and/or related parties.

The second part of marketing organizations, namely LLC "Pharm-Rost Plus," LLC "Spectrum Pharm”. The final beneficiaries are the second group of related parties.

Under the same schemes LLC "OMP Marketing", LLC "Galapharm”, LLC “TMSKO”, LLC "Armantis", LLC "Medlist Marketing", LLC "Smart Pharma" are working.

It should be noted that the initiators of marketing agreements, along with the owners of pharmacy chains, are pharmaceutical manufacturers and / or their representatives.

Thus, according to the Antimonopoly Committee of Ukraine set out in the recommendations of the Ministry of Health dated 16.09.2018, which by the way have not been implemented, it is recorded that the initiators of such marketing are importers, domestic manufacturers, marketing organizations, and some pharmacy chains "[10].

At the same time, importers, domestic manufacturers, marketing organizations enter into marketing agreements with pharmacy chains both independently and through intermediaries.

Returning to the real state of affairs in Ukraine, we note that, as a survey of middle managers showed, the greater the volume of goods of a particular manufacturer, then, of course, the greater the amount of payments under marketing contracts. Pricing in the presence of marketing payments, conditionally, occurs according to the following scheme, for example $100+50=100$.
That means that the pharmacy chain or association of pharmacy chains buys one name of a medicinal product from a pharmaceutical manufacturer for UAH 100 and, at the same time, still receives, in addition to the goods, an additional $50 \mathrm{UAH}$ under the marketing contract for recommending this item to the patient. While receiving such funds, it does not make sense to the pharmacy owner to additionally overprice the goods; he already has 50 percent of the value of the goods, which, moreover, is not correctly taxed and accounted for under the "gray scheme". According to one of the participants in the pharmaceutical market, the director of a small company "Aesculapius": “" manufacturers, in order not to remain at a loss, under the pressure of mega-networks and monopolized markets are forced to inflate the price by $40 \%$, and give this interest to mega-networks. At the same time, mega-networks have the opportunity to dump and thus destroy small pharmacy chains, which are faced with the need to purchase drugs from distributors at manufacturer's prices, inflated in connection with marketing agreements by $20-40 \%$ "[11].

However, this scheme is valid only for large volumes of goods, so small pharmacy chain owners cannot afford to use such a scheme. And they, buying goods from the manufacturer at the same price, are additionally overpricing them to cover their own costs and pay the appropriate taxes. As a result, they do not withstand competition and are gradually eliminated. If they continue their activities, then mainly in rural areas, where large pharmacy chains are not very profitable.

According to Proxima Research, the average revenue of one pharmacy of a legal entity is UAH 455.6 thousand per month, and a pharmacy owned by a private entrepreneur only 140.4 thousand UAH per month [12]. And the reason for the big difference in revenue is not only in the placement of pharmacies, but a more important reason is the conclusion of so-called marketing agreements. Simply no one concludes them with small pharmacy chains because of the small volume of drug sales, however, the main burden on the location of pharmacies in sparsely populated areas is borne by them.

In fact, the description of this scheme provides an answer to the question: who exactly forms the prices? Our hypothesis is confirmed by other participants in pharmacy activity.

For example, the director of the Public Union "Pharmacy Professional Association of Ukraine" has repeatedly drawn attention to the fact that the final cost of drugs is never formed in the pharmacy. Most of all, the formation of their value, he rightly believes, is influenced by the manufacturer [13]. He believes that prices depend only on the manufacturer [14].

And indeed, the price is truly formed by the manufacturer of pharmaceutical products, while the retail markup of the pharmacy remained fixed - up to 15 percent. However, the question remains: why should a manufacturer invest up to 50 percent of their cost in the pricing of medicines in order to pay individual pharmacies under "gray" schemes for so-called marketing services? And why don't all pharmacies get paid for marketing services? 
To answer this question, let us analyze the structure of the pharmacy market of Ukraine:

1) Under the brand "Apteka nyzkykh tsin", which unites 18 legal entities in different regions of Ukraine operates 900 pharmacies [15], under the logo "ANTs", "Apteka nyzkykh tsin", "Blagodiya", "Kopiyka”.

The founders and ultimate beneficiaries of these entities are related parties.

2) The private company "Gamma-55" has a brand "Pharmacy Network 9-1-1" [16] and according to the application PharmXplorer of company "Proxima Research", it can be noted that these persons have 700 pharmacies under their control [15], operating under the logo Pharmacy 9-1-1 ", "Apteka optovykh tsin". At the same time, all these logos are on the facades of such subjects of pharmacy activity as PE «Firma Mahiia Farm», LLC “Apteka 97”, LLC Elroi Menedzhment, LLC “Tsentralna raionna apteka №16”, LLC "Danunts”, LLC “TVAHRUPP", PE “Apteka 211", LLC «Ie APTEKA». The ultimate beneficiaries are related parties

3) Sirius-95 LLC, a network of pharmacies "Bazhaiemo zdorovia", according to the license register, in the amount of 709 units [17], and according to the PharmXplorer application of the company "Proxima Research" - 800 pharmacies [15] and covers all regions countries other than the occupied.

4) PE "SOLOMIA-SERVICE" operates under the logo "Plantain", unites 24 legal entities in different regions of Ukraine and has 638 pharmacies under its control [17].

5) LLC "Pharmastor" together with LLC "Apteka dobroho dnya" work under the brand "Apteka dobroho dnya" and control according to the application PharmXplorer company "Proxima Research" 500 pharmacies [15].

6) Med-Service Group LLC unites fourteen legal entities and controls 400 pharmacies [17].

7) LLC "Market Universal LTD". The company is engaged in pharmaceutical activities virtually throughout Ukraine. The company has two pharmacy chains - "D.S." and "Apteka nashoho mista", which unites five legal entities and controls 768 pharmacies [17].

8) The network of pharmacies "Zdorova rodyna" consists of the Private Enterprise "Pharmaceutical Company" Zdorova rodyna"' and LLC "Pharmaceutical Company "Zdorova rodyna"', LLC "Salve", LLC "Romashka" and controls 254 pharmacies [17].

9) PJSC "Aptechna merezha "Farmatsiya"” controls 213 pharmacies [17] in Odessa, Kyiv, Mykolaiv and Kherson regions.

10) LLC " $3 i$ " according to the Lviv Chamber of Commerce and Industry has about 100 pharmacies in Lviv, Ternopil, Ivano-Frankivsk, Zakarpattia, Rivne, Khmelnytsky and Chernivtsi regions. Further, if you analyze the information sites of Lviv, in particular "LVIV ONLINE" [18], you can find some addresses of the network of pharmacies LLC " $3 i$ ", but it is interesting that at those addresses, pharmacies which, according to the license register, belong LLC "Apteka Doviry" [17], but the logos on the facades of these pharmacies are called "Apteka 3i" [19]. Further interesting is the fact of the existence of LLC "Apteka 3i", the legal address in Mykolaiv, the beneficiary of the company "Sunrise Holding International Limited" Belize, the final beneficiary Jozelin Quiros, Costa Rica. Furthermore, this company's official partner is already known to us LLC "Apteka Doviry", in which according to the License Register, 50 pharmacies are registered [21]. In addition, among the partners of groups of companies " $3 i$ " there are [17] pharmacy chain "LLC "Lider-Zakhid", operating under the logo Pharmacy "SIDUS" [17], according to the license register has 57 pharmacies and 8 pharmacies. Also among the partners there are the network of pharmacies "Etalon zdorovya" [17], the addresses of pharmacies allow to establish according to the license register that they belong to LLC "Firma "Medfarm", in the amount of 71 pharmacies [17].

Thus, the company " $3 i$ ", including through offshore, controls 186 pharmacies.

11) LLC "Tas-Pharma" operates under the brand pharmacy chain "Apteka TAS" ta "Apteka pryyemnykh tsin" and control 141 pharmacies [17].

12) Volynpharm in the form of a limited liability company - a network of pharmacies in the Western region of Ukraine, covers Volyn, Lviv, Rivne, Ternopil, Ivano-Frankivsk, Zhytomyr and Khmelnytsky regions. According to the License Register, it consists of 119 pharmacies and drugstores [17].

13) LLC "Ukrayins'kyy aptechnyy kholdynh" was established on the basis of pharmacy chains "Dobri liky", "Zdravitsa" and a subsidiary "Tsentral'na rayonna apteka №147” LLC “Sigma Rent”. The network of pharmacies "Dobri liky" includes, according to the license register [17] - 53 pharmacies, "Zdravytsa" - 21 pharmacies. However, according to PharmXplorer's Proxima Research application [15], the LLC "Ukrayins'kyy aptechnyy kholdynh" controls 100 pharmacies.

14) LLC "Rehional'na aptechna merezha Ruan", consists, according to the license register of 99 pharmacies [17].

15) Vitalux LLC, according to the license register, has 40 pharmacies [17]. Together with this company works in the market of LLC "APTEKAR-GROUP", according to the license register has 58 pharmacies [17], the final beneficiaries are related parties [18]. Both legal entities position themselves as a single network of pharmaceutical markets and operate under the brand "Vitalux + APTEKAR". A total of 98 pharmacies are under control. 16) Private enterprise "Konex" [22], place of activity - Vinnytsia, Chernivtsi and Khmelnytsky regions. According to the license register there are 63 pharmacies and drugstores [17].

In total, the pharmacy entities unite at least 5,595 pharmacies, and it is only the minimum that could be established by analyzing the activities of these entities and their affiliates.

Meanwhile, according to the state quality control of medicines [23], the number of pharmacies in the dynamics over the past three years can be seen in Table 2 . 
Table 2. The number of pharmacies in the dynamics (2018 - 2020)

\begin{tabular}{cccc} 
& $\mathbf{0 1 . 0 1 . 2 0 1 8}$ & $\mathbf{0 1 . 0 1 . 2 0 1 9}$ & $\mathbf{0 1 . 0 1 . 2 0 2 0}$ \\
\hline Total pharmacies, of which: & 17920 & 17670 & 17425 \\
\hline Legal entities & 12278 & 12611 & 12868 \\
\hline Individuals & 5642 & 5059 & 4557 \\
\hline Total pharmacies, including: & 4690 & 4445 & 4215 \\
\hline Legal entities & 3675 & 3547 & 3385 \\
\hline
\end{tabular}

The analysis of the activities of those subjects that we have identified is impressive. Based on the fact that one pharmacy's average revenue per month is 455.6 thousand $\mathrm{UAH}$, the total amount for all pharmacies that we analyzed is 2,549,082,000 UAH. In total, this figure will amount to UAH 30,588,984,000 per month for the year, which is equal to 926 million 938 thousand 910 euros at the exchange rate of the National Bank of Ukraine.

Thus, if we conditionally deduct the 50 percent that these companies receive under marketing agreements, this figure will be UAH 15,294,492,000 or approximately EUR 464 million.

However, these calculations are confirmed by the information of Proxima Research in 2019, which states that the consolidation of pharmacy retail is actively underway and, over the past two years, the share of top 100 pharmacy chains in terms of pharmacy sales in the monetary form increased to 74.5 percent [24 ]. It makes no sense to recall that most of these pharmacy companies use their advantages to protect their monopoly position in order to increase revenue from the provision of alleged marketing services. Moreover, it is they who dictate the rules of conduct in the pharmaceutical market, and, for the most part, pharmaceutical manufacturers are forced to comply with the requirements of these mega-networks in terms of concluding marketing agreements. That is why manufacturers include in the cost of medicines, the cost of marketing services, which reach 50 percent of the product's actual price. As a result, small pharmacies fail to compete and cease operations. In this context, the question arises: what will happen in the pharmacy market when these mega-networks finally become one hundred percent monopolists? It is clear that the question is rhetorical and does not even need an answer.

Manufacturers can be understood, says one of the subjects of pharmacy. For example, two large manufacturers - conditionally, there are manufacturers "A" and "B". They have a lot of similar products. Now imagine that several large mega-networks unite in the matter of "wringing the hands" of one of the manufacturers. To achieve this goal, they readily agree with each other and simultaneously stop buying products from one manufacturer in favor of another. Of course, the consumer will not notice that because drugs with a particular active ingredient will not disappear from pharmacies. And what will happen to the manufacturer against which the anti-competitive actions have started? He will be forced to negotiate on the terms dictated by mega-networks. And all this is already happening in the Ukrainian pharmaceutical market [11].

What conclusions should be drawn from the information provided?

1) The price of medicines in Ukraine is artificially inflated by almost 50 percent, significantly reducing their availability for patients. In many cases, it makes treatment virtually impossible due to lack of funds. This situation directly affects the life expectancy and quality of life of Ukrainians, which are much lower than in neighboring European countries.

2) The pharmacy market is monopolized by national mega-networks, which methodically and consistently displace from the market the remnants of professionals who, for many years, and sometimes even several generations, carried out pharmaceutical activities. They are being replaced by non-specialists who, under the brands of national mega-networks, are engaged in distributing drugs and their unprofessional, and in many cases extremely harmful to the patient's health promotion. It is not uncommon for a pharmacist to strongly recommend medication to a patient that is not only unnecessary but is dangerous to his or her health, given the diagnosis and other medications he or she is using.

3) National mega-networks, demanding from pharmaceutical manufacturers up to 50 percent of the cost of goods for so-called marketing services, on the one hand, ruthlessly destroy professional pharmaceutical activities, on the other - artificially inflate drug prices and lure them with dishonest marketing.

4) These monopolists, having large funds and enjoying virtually complete impunity, are actively lobbying to protect their interests through influential public organizations, representatives of the legislature, and the executive. That may explain the categorical reluctance to legally implement the successful experience of neighboring countries in limiting the monopolization of the pharmacy market and lowering the prices of medicines.

\section{CONCLUSIONS}

Further consequences of the consolidation of pharmacy chains can be observed:

1) The pharmaceutical industry will be virtually destroyed, leaving only those who agree to merge with large pharmacy chains or to transfer controlling stakes in their companies to such final beneficiaries of retail pharmacy chains. Even today, in the conditions of monopolization 
of the retail pharmacy market, Ukrainian pharmaceutical manufacturers are losing their economic attractiveness to foreign investors;

2) The existence of pharmaceutical distributors will be questioned, their functions, in the absence of competition, will be significantly limited, and it would be logical to covertly merge with large pharmacy chains (including by assigning controlling stakes);

3) Small retail pharmacies cannot compete and will be destroyed. Analysis of the pharmacy market shows that the process of active destruction of such entities has been observed for the last three years.

4) Due to the monopolization and the above perspective of the pharmaceutical market, there will be a further increase in prices for pharmaceutical products for end-users (patients and medical institutions), including due to the further spread of marketing agreements that force pharmaceutical manufacturers to shift this burden on the shoulders of end consumers.

\section{REFERENCES}

1. Bondarchuk I. Monopoliya v aptechnom segmente. CHto vazhnee kolichestvo ili kachestvo? [Monopoly in the pharmacy segment. What is more important - quantity or quality?] Ezhenedel'nik APTEKA. 2018; 32(1153): 5-6(Ru).

2. Rosalind Miller and Catherine Goodman Do chain pharmacies perform better than independent pharmacies? Evidence from a standardised patient study of the management of childhood diarrhoea and suspected tuberculosis in urban India. BMJ Glob Health. 2017; 2(3): e000457. Available from: https://www.ncbi.nlm.nih.gov/pmc/articles/ PMC5623271/ [reviewed 2020.08.10].

3. Rosalind Miller, Eleanor Hutchinson, Catherine Goodman 'A smile is most important.' Why chains are not currently the answer to quality concerns in the Indian retail pharmacy sector. Social Science \& Medicine. September 2018;212: $9-16$.

4. The legal and regulatory framework for community pharmacies in the WHO European Region. Available from: https://apps.who. int/iris/bitstream/handle/10665/326394/9789289054249-eng. pdf?sequence $=1 \&$ isAllowed $=y$ [reviewed 2020.08.10].

5. Judgment of the Court (Grand Chamber) of 19 May 2009 - Commission of the European Communities v Italian Republic (Case (-531/06). Available from: https://eur-lex.europa.eu/legal-content/EN/ TXT/?qid=1577302098173\&uri=CELEX:62006CA0531 [reviewed 2020.08.10].

6. Solovov 0.S. Perspektyvy vplyvu aptechnoho samorehuliuvannia na diialnist aptechnykh merezh. [Prospects for the impact of pharmacy self-regulation on the activities of pharmacy networks.] FARMAKOM. 2019;3:63- 67 (Ua).

7. USTAWAzdnia 6 września 2001 r. Prawo farmaceutyczne. Available from: http://isap.sejm.gov.pl/isap.nsf/download.xsp/WDU20011261381/U/ D20011381Lj.pdf [reviewed 2020.08.10].

8. 2011. évi CLXXVI. törvény az egyes egészségügyi tárgyú törvények módositásáról. hatályos: 2011.12.15. Available from: https://www. hbcs.hu/uploads/jogszabaly/974/fajlok/2011_CLXXVI_tv.pdf [reviewed 2020.08.10].

9. Prykhodko 0. Rehuliuvaty potribno ves lantsiuh postachannia preparativ, a ne okremi lanky -Svitlana Panaiotidi. [It is necessary to regulate the entire supply chain of drugs, not individual units - Svetlana Panaiotidi] Ezhenedelnyk APTEKA. 2018;38(1159):10 - 11 (Ua).
10. Rekomendatsii Antymonopolnoho komitetu Ukrainy Ministerstvu okhorony zdorovia Ukrainy vid 16.09.2018 roku [Recommendations of the Antimonopoly Committee of Ukraine to the Ministry of Health of Ukraine dated September 16, 2018] Available from: http://www. amc.gov.ua/amku/doccatalog/document?id=144248\&schema=main [reviewed 2020.08.10] (Ua).

11. Lev Braginskij: «Monopolizaciya farmrynka Ukrainy — sostoyavshijsya fakt».[ Monopolization of the pharmaceutical market of Ukraine is an accomplished fact] SHCHotizhnevik APTEKA. 2018; 29(1150). Available from: https://www.apteka.ua/article/465170 [reviewed 2020.08.10] (Ru).

12. Infrastruktura aptechnogo ritejla: na poroge izmenenij. [Pharmacy retail infrastructure: on the verge of change] Ezhenedel'nik APTEKA.2019; 4 (1175). Available from: https://www.apteka.ua/article/487942 [reviewed 2020.08.10] (Ru).

13. Prokhorenko Ye. Yak vrehuliuvaty diialnist operatoriv farmrynku, aby zabezpechyty dostupnist likiv? [How to regulate the activities of pharmaceutical market operators to ensure the availability of medicines?] Shchotyzhnevyk APTEKA. 2018;22(1143). Available from: https://www.apteka.ua/article/459172 [reviewed 2020.08.10] (Ua).

14. Konstruktyvnyi dialoh iz vladoiu ta spilne vyrishennia nahalnykh pytan: spodivannia APAU. [Constructive dialogue with the authorities and joint solution of urgent issues: hopes of the UAPA.] Shchotyzhnevyk APTEKA. 2019;41(1212). Available from:https://www.apteka.ua/article/519467 [reviewed 2020.08.10] (Ua).

15. PharmXplorer. PharmXplorer is a group of analytical dashboard applications for pharmaceutical market players. Available from: https:// pharmxplorer.com.ua/login [reviewed 2020.08.10].

16. Apteka 9-1-1. Available from: https://apteka911.com.ua/map/ukraina [reviewed 2020.08.10].

17. Derzhavna sluzhba likarskykh zasobiv ta kontroliu za narkotykamy. Reiestr mists provadzhennia diialnosti z optovoi ta rozdribnoi torhivli LZ. [State Service for Medicines and Drug Control. Register of places of activity on wholesale and retail trade of medicinal products.] Available from: http://pub-mex.dls.gov.ua/TradeLicense/TradeLicenseList.aspx [reviewed 2020.08.19] (Ua).

18. Merezha aptek «3i». [Chain of pharmacies "3i".] Available from: https://lviv-online.com/ua/medicine/chemistry/apteka-3i/[reviewed 2020.08.19] (Ua).

19. Naiholovnishe dlia uspishnoi kariery - komunikatsiini navychky ta mozhlyvist otrymannia porad vid profesionaliv. [The most important things for a successful career are communication skills and the possibility of obtaining advice from professionals.] Available from: https://financial.Inu.edu.ua/news/najholovnishe-dlya-uspishnojikarery-komunikatsijni-navychky-ta-mozhlyvist-otrymannya-poradvid-profesionaliv [reviewed 2020.08.19] (Ua).

20. TOV «Apteka Doviry». [LLC «Pharmacy of Trust»]] Available from: https:// dovira.farm/ [reviewed 2020.08.19] (Ua).

21. Yedynyi derzhavnyi reiestr yurydychnykh osib, fizychnykh osibpidpryiemtsiv ta hromadskykh formuvan [Unified State Register of Legal Entities, Individual Entrepreneurs and Public Associations] Available from: https://usr.minjust.gov.ua/content/home [reviewed 2020.08.19] (Ua).

22. Yedynyi derzhavnyi reiestr yurydychnykh osib, fizychnykh osibpidpryiemtsiv ta hromadskykh formuvan [Unified State Register of Legal Entities, Individual Entrepreneurs and Public Associations] Available from: https://usr.minjust.gov.ua/content/home [reviewed 2020.08.19] (Ua). 
23. Derzhavna sluzhba likarskykh zasobiv ta kontroliu za narkotykamy. Derzhavni reiestry. [State Service for Medicines and Drug Control. State registers.] Available from: https://www.dls.gov.ua/ [reviewed 2020.08.19] (Ua).

24. Dmitrik E. Infrastruktura aptechnogo ritejla: na poroge izmenenij. [Pharmacy retail infrastructure: on the verge of change.] SHCHotizhnevik APTEKA. 2019;4(1175) Available from: https://www.apteka.ua/ article/487942 [reviewed 2020.08.10] (Ru).

\section{ORCID and contributionship:}

Nataliya O. Gutorova: 0000-0003-2485-0651 A,B,D,E,F

Vitalii M. Pashkov: 0000-0001-9489-7768 ${ }^{A, B, D, E, F}$

Oleksii S. Soloviov: 0000-0002-6615-4868 ${ }^{A, B, D, E, F}$

\section{Conflict of interest:}

The Authors declare no conflict of interest.

\section{CORRESPONDING AUTHOR}

\section{Vitalii M. Pashkov}

Poltava Law Institute of Yaroslav Mudriy

National Law University, Poltava, Ukraine

tel: +380666931651

e-mail:v.pashkov26.06@ukr.net

Received: 04.09.2020

Accepted: 30.11 .2020

A - Work concept and design, B - Data collection and analysis, C - Responsibility for statistical analysis,

D-Writing the article, $\mathbf{E}$-Critical review, $\mathbf{F}$ - Final approval of the article 